\title{
Green remediation. Tool for safe and sustainable environment: a review
}

\author{
Mamta Singh $^{1} \cdot$ Gaurav Pant $^{1} \cdot$ Kaizar Hossain $^{2}$ - A. K. Bhatia ${ }^{1}$
}

Received: 26 February 2016/Accepted: 31 August 2016/Published online: 16 September 2016

(C) The Author(s) 2016. This article is published with open access at Springerlink.com

\begin{abstract}
Nowadays, the bioremediation of toxic pollutants is a subject of interest in terms of health issues and environmental cleaning. In the present review, an ecofriendly, cost-effective approach is discussed for the detoxification of environmental pollutants by the means of natural purifier, i.e., blue-green algae over the conventional methods. Industrial wastes having toxic pollutants are not able to eliminate completely by existing the conventional techniques; in fact, these methods can only change their form rather than the entire degradation. These pollutants have an adverse effect on aquatic life, such as fauna and flora, and finally harm human life directly or indirectly. Cyanobacterial approach for the removal of this contaminant is an efficient tool for sustainable development and pollution control. Cyanobacteria are the primary consumers of food chain which absorbed complex toxic compounds from environments and convert them to simple nontoxic compounds which finally protect higher food chain consumer and eliminate risk of pollution. In addition, these organisms have capability to solve secondary pollution, as they can remediate radioactive compound, petroleum waste and degrade toxins from pesticides.
\end{abstract}

Keywords Toxic pollutants - Bioremediation . Cyanobacteria $\cdot$ Sustainable development

Gaurav Pant

rgauravpant@gmail.com; gaurav.pant@gla.ac.in

1 Department of Biotechnology, Institute of Applied Sciences and Humanities, GLA University, Mathura, UP, India

2 School of Industrial Technology, Universiti Sains Malaysia, Pulau Pinang, Malaysia

\section{Introduction}

Pollution is the addition of pollutant to the environment that causes an adverse effect to the life. There are different types of pollution, but among them, water pollution is an important subgroup. Water is the vital component for life. Surface water and ground water are the major sources of drinking water in rural and urban areas, but due to high industrialization in the recent past decades, the quality has been severely affected (Bharti et al. 2013). Due to industrial revolution, various industries, such as chemical, nuclear, textiles, oil refinery, etc., come in existence, which are a major concern (Persson and Destouni 2009). The problem of water pollution arises due to the release of organic and inorganic pollutants by anthropogenic activity which creates and causes severe health damage (Raouf et al. 2012). Direct disposal of effluents containing pollutants results in the toxicity of surface water bodies and land around industrial areas which leaches down and contaminates ground water bodies to their high density (Prabha et al. 2013). Aquatic system gets to accumulate with high risk of toxins which in turn mixed and transfer into the food chain and finally reaches to humans (Shaikh and Bhosle 2011). After entering into human body, these pollutants cause severe damage to health in terms of renal, cardiovascular, and neurological disorders and are even life threatening (Table 1). It has also been reported that nickel and chromium have a carcinogenic effect on human health (Duruibe et al. 2007).

Various physical and chemical methods are used for the detoxification of effluents, but rather than complete degradation, they only change their forms. These changed forms are even toxic and have ability to cause damage even in a very low concentration (Noel and Rajan 2014). Bioremediation over the conventional methods is most 
Table 1 Pollutants causes health damage in humans

\begin{tabular}{lll}
\hline Pollutants & Disorders & References \\
\hline Lead & Neurotoxic, anaemia, high blood pressure & Kim et al. (2015) \\
Arsenic & Hypo-pigmentation, cancer & Biswas et al. (2015) \\
Cadmium & Kidney damage, cancer & Vilahur et al. (2015) \\
Chromium & Cancer, ulceration, nephritis & Sun et al. (2015) \\
Nickel & Chronic disorder of lungs, bones & Wang et al. (2015) \\
Mercury & Neurotoxic, respiratory disorder & Castilhos et al. (2015) \\
Pesticides & Neurotoxicity, cancer & Tomer et al. (2015) \\
Benzene & Carcinogenic effect & Kponee et al. (2015) \\
Uranium & Mental retardation, estrogenic effect & Brugge and Buchner (2011) \\
Polycyclic aromatic hydrocarbon & DNA damage and mutations & Kponee et al. (2015) \\
\hline
\end{tabular}

promising technology for cleaning environment. In addition, it is an eco-friendly, cost-effective technique having properties for possible recovery of elements and can solve environmental problems related to water (Sahu 2014). The basic protocol of bioremediation and recovery of useful products involve numerous steps, such as selection of biomass (cyanobacterial strain), pre-treatment, immobilization, desorption, etc., as shown in Fig. 1.

Cyanobacteria are aquatic photosynthetic prokaryotes persist more than 3 billion years having unremarkable potential in the treatment of waste water and bioremediation of toxic pollutants from effluents and solutions (Noel and Rajan 2014; Priyadarshani et al. 2011; Rastogi et al. 2014). Recently, there has been an increasing attentiveness about using cyanobacteria as biocontrol agents, either as wild type, mutant or genetically engineered forms (Ananya and Ahmad 2014; Noel and Rajan 2014).

Fig. 1 Schematic representation of biosorption with possible recovery
Cyanobacterial bioremediation is based on the idea to take complex pollutants from the environment and use them to boost for their augmentation and metabolism, or renovate them from a toxic to a nontoxic form (Quintana et al. 2011). These cells have high efficiency for binding pollutants, such as toxic metal ions, due to the presence of various lipids, proteins, and polysaccharides receptors on their surface (Priyadarshani et al. 2011). When the toxic complex pollutants are trapped by surface receptors, they bind passively to the cellular structure the phenomena known as "Biosorption", while the utilization of these pollutants in metabolic cycle after crossing via cell membrane actively is referred to as "Active uptake". Both passive biosorption and active uptake of pollutants by cyanobacterial cell are termed "Bioaccumulation", and the phenomenon is referred to as phycoremediation tool (Malik 2004; Sharma 2012). However, the phenomenon can be

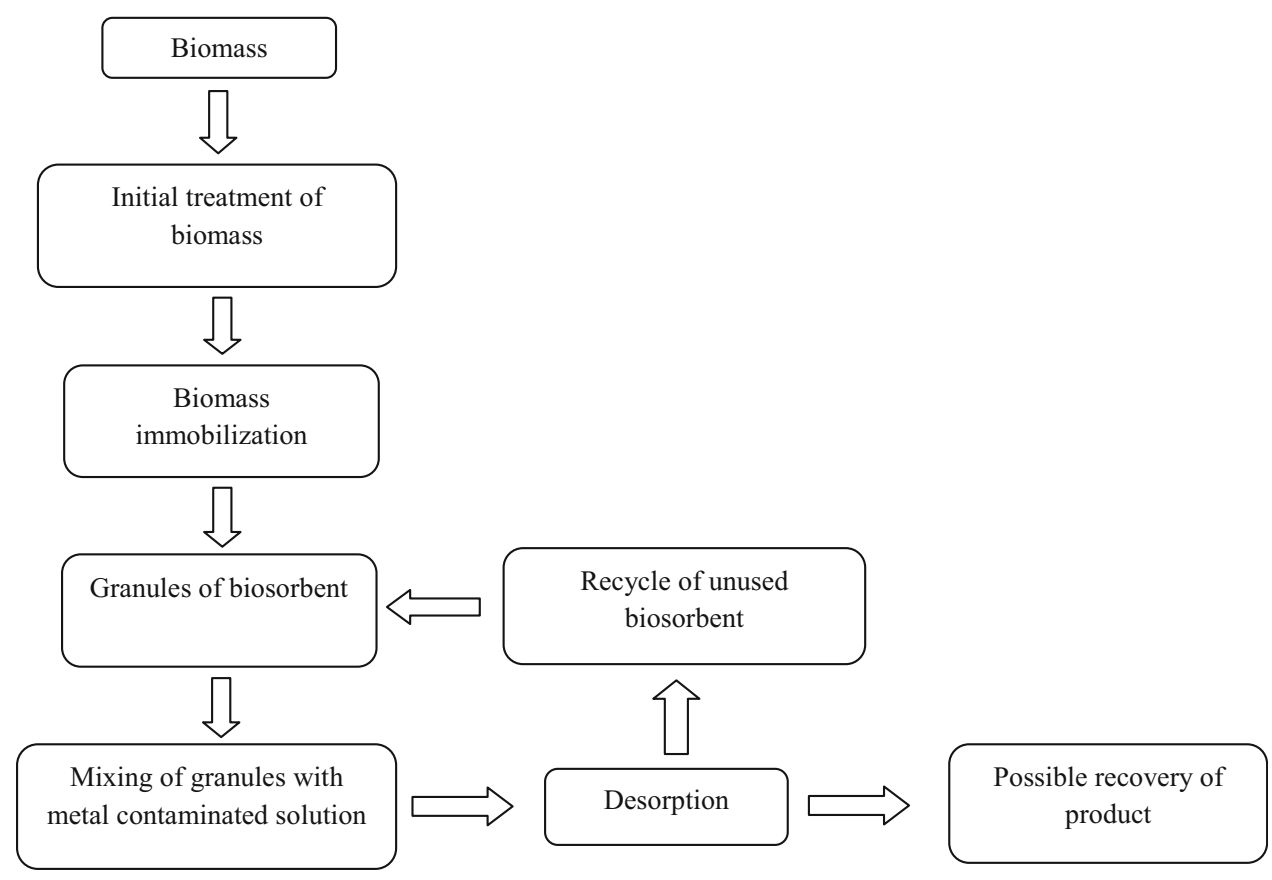


influenced by various factors, including environmental conditions, contaminants, other microbes, etc., as mentioned in Fig. 2 (Rastogi et al. 2014).

\section{Bioremediation of heavy metals}

Heavy metals are well-known hazardous pollutants which show a lethal effect on biological cycles of aquatic species due to changes in the conformational configuration of nucleic acids, proteins, and osmotic balance (Sivakumar et al. 2012). The consequence of metal toxicity is not limited to aquatic bodies, but also affects soil flora, plant, animals, and finally to humans. It causes damage to cell morphology and inhibits the cytoplasmic enzyme due to oxidative stress (Bulgariu and Bulgariu 2014). In general, these metals exist naturally either alone or in combination with other elements, but anthropogenic activity enhances their concentration in environment (Ebtesam et al. 2013). Mainly, heavy metals get dissolved in solutions due to their water soluble property, which cause difficulties in their elimination via physical and chemical separation methods. Waste water treatment depends on the precipitation or adsorption of suspended solids, while the use of bio-adsorbent, such as algae, depends on the accumulation of heavy metals (Volesky and Naja 2007). Cyanobacterial approach is an alternative tool for complete removal of heavy metal pollutants with low toxicity due to their cultivate autotrophically and heterotrophically, as well as potential for genetic manipulation (Table 2) (Mitra et al. 2012; Sahu 2014).

In addition to remediation, various studies suggest possible metal recovery from cyanobacterial strains after the treatment of polluted water bodies (Table 3) (Lata et al. 2015).

\section{Bioremediation of oil}

Discharge of liquid petroleum contaminant, i.e., crude oil, and their by-products into water bodies due to anthropogenic activities enhance risk in aquatic environment (Almeda et al. 2014). Yearly, $48 \%$ of oil contamination in the oceans is due to fuels and $29 \%$ by crude oil (Brekke and Solberg 2005). Annually, approximately 35 million barrels petroleum has been transport across the world which is an important source of oil contamination (Zaki et al. 2015). In addition, oil refinery discharge is another source which creates pollution in aquatic system (Obaidy and Lami 2014). Oil contamination in rivers and oceans may have effect for short term and long term. Short-term effects include oil toxicity, reduction in dissolved oxygen and light transmission which affects the photosynthetic activity of aquatic organisms. The long-term effect includes a change in the biological process, such as reproduction, food disappearance, and habitat destruction. In addition, it also causes genetic disturbance in aquatic life especially when contaminated with polycyclic aromatic hydrocarbons (PAH) (McGenity et al. 2012).

$\mathrm{PAH}$ is originated by incomplete fuel combustion or petroleum derivatives spill out (Dabestani and lvanov 1999). These are highly toxic pollutants which show mutagenic and carcinogenic effect when comes in contact with life either by the means of direct contact or via food chain (Perelo 2010). PAH degradation by the conventional methods is not very easy, as they accumulate in the sediment due to their high molecular weight, low water solubility, and hydrophobicity (Hong et al. 2015). Hence, there is an urgent need for appropriate management to solve such problems and to develop technologies which are more effective and resource conservative. Various studies demonstrate unremarkable potential of algal remediation for removing crude oil and their toxic by-products (Table 4) (Houser et al. 2014; Olajire and Essien 2014). From crude oil, 38-60\% saturated hydrocarbon and $12-41 \%$ aromatic hydrocarbon degraded using cyanobacteria, while 10-23\% of aliphatic hydrocarbon and 10-26\% aromatic compound from motor oil (Priyadarshani et al. 2011).

\section{Bioremediation of pesticides}

Pesticides are the toxic chemicals which are specifically used in fields for removing pests including insects, weeds,
Fig. 2 Influencing factors for cyanobacterial bioremediation

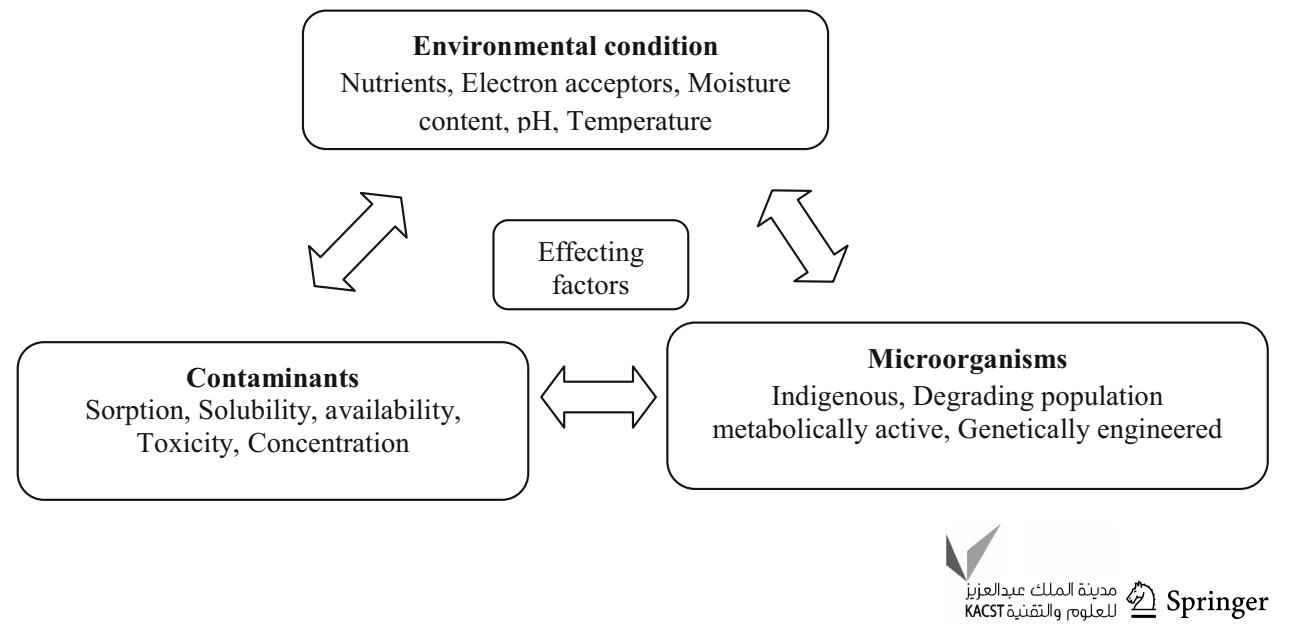


Table 2 Heavy metal bioremediation through algae

\begin{tabular}{lll}
\hline Algae & Metal & References \\
\hline Lyngbya putealis & $\mathrm{Cu}, \mathrm{Co}$ & Kiran and Thanasekaran (2011) \\
Sargassum myriocystum & $\mathrm{Pb}$ & Sweetly and Sangeetha (2014) \\
Enteromorpha intestinalis & $\mathrm{Mn}, \mathrm{Zn}, \mathrm{As}$ & Homaidan et al. (2011) \\
Cladophora glomerata & $\mathrm{Cu}, \mathrm{Cd}, \mathrm{Pb}$ & Homaidan et al. (2011) \\
Ulva lactuca & $\mathrm{Pb}, \mathrm{Zn}, \mathrm{Co}$ & Bulgariu and Bulgariu (2014) \\
Euglena gracilis & $\mathrm{Cd}, \mathrm{Zn}$, and $\mathrm{Pb}$ & Cózatl et al. (2006) \\
Scenedesmus sp. & $\mathrm{Cu}, \mathrm{Ni}, \mathrm{Cd}, \mathrm{Zn}$ & Halder (2014) \\
Chlorella vulgaris & $\mathrm{Cu}, \mathrm{Cr}, \mathrm{Pb}, \mathrm{Ni}, \mathrm{Zn}$ & Thongpinyochai and Raymond (2014) \\
Phormidium sp. and Oscillatoria $\mathrm{sp}$. & $\mathrm{Cr}$ & Shukla et al. (2012) \\
Spirogyra sp. and Oscillatoria sp. & $\mathrm{Cd}$ & Brahmbhatt et al. (2012) \\
\hline
\end{tabular}

Table 3 Recovery of metals from waste water through algae

\begin{tabular}{lll}
\hline Metal & Organism & References \\
\hline $\mathrm{Cd}$ & Durvillaea potatorum & Matheickal et al. (1999) \\
$\mathrm{Pb}$ & Oedogonium sp. and Nostoc sp. & Gupta and Rastogi (2008) \\
$\mathrm{Ni}$ & Chlorella sorokiniana & Akhtar et al. (2004) \\
$\mathrm{Hg}$ & Chlorella emersonii & Bashan and Bashan (2010) \\
$\mathrm{Cr}$ & Lyngbya putealis & Kiran et al. (2007) \\
\hline
\end{tabular}

Table 4 Degradation of petroleum compounds and fuel components by algae

\begin{tabular}{lll}
\hline Algae & Compound & References \\
\hline Selenastrum capricornutum & Benzene, toluene, pyrene & Chekroun et al. (2014) \\
Cyanobacteria (Blue-green algae) & Benzene, toluene, phenanthrene, pyrene & Semple et al. (1999) \\
Oscillatoria spp. & $n$-Alkanes & Abed and Koster (2005) \\
Scenedesmus obliqus & Parathione, sulfonic acids & Semple et al. (1999) \\
Euglena gracilis & Phenol & Semple et al. (1999) \\
Prototheca zopfi & Crude oil and a mixture of hydrocarbons & Xenia and Refugio (2016) \\
\hline
\end{tabular}

pathogenic fungi, rodents, etc (Rani and Dhania 2014). However, excessive use may results in the aggregation of these chemicals in agricultural product, soil, surface water, as well as ground water (Mohany et al. 2011). The phenomena of aggregation may result in geno and cytotoxicity, dysfunctioning of immune system, reduction of reproductive health, and even mortality (Gibbons et al. 2015). In addition, it may also enhance risks to ecosystem and affect a wide range of soil and water microflora. Invertebrates, such as earth worm, which are essential for soil processes, are found to be more sensitive for sublethal and lethal effects of these insecticides (Chagnon et al. 2015). Harmful compounds, such as organochlorine and organophosphorus, are introduced into an aquatic system by agriculture run-off (Karunya and Saranraj 2014).

The rate of degradation process depends on selected algal strain and nature of pesticide which can be influenced by environmental conductions ( $\mathrm{pH}$, salinity, oxygen tension, nutrients, water, temperature, light intensity, etc.) and physicochemical properties (molecular weight, concentration, chemical structure, toxicity, etc.), respectively (Varsha et al. 2011; Priyadarshani et al. 2011) (Table 5).

\section{Bioremediation of radioactive compounds}

In our environment, radioactive compounds have been released from several decays by various anthropogenic activities. Unlike industrial effluent, radionuclide comes into surroundings from metallurgical mining, nuclear power test, discharge from nuclear reactors, etc. The toxicity of radioactive compound is furthermost environmental anxiety which poses a major concern for health issue and is serious threat for life. Various studies revealed a lethal effect on human health due to direct contact, including the risk of leukaemia, leucopenia, kidney damage, and even genetic disorders (Prakash et al. 2013). While indirect transmission of this toxic radionuclide via food chain also causes serious health hazards. After 
Table 5 Microalgae in the bioaccumulation of pesticides

\begin{tabular}{lll}
\hline Microalgae & Pesticides & References \\
\hline Chlamydomonas reinhardtii & Herbicide fluroxypyr & Zhang et al. (2011) \\
Chlorella sp. & Toxaphene, Methoxychlor & Semple et al. (1999) \\
Chlorococcum sp. & Mirex & Semple et al. (1999) \\
Synechococcus elongates, Microcystes & Organophosphorus and & Vijayakumar (2012) \\
aeruginosa & organochlorine & \\
Euglena gracilis & DDT, parathion, phenol & DeLorenzo et al. (2001) \\
Scenedesmus obliquus & DDT, parathion & Semple et al. (1999) \\
Dunaliella sp., Cylindrotheca sp. & Naphthalene, DDT & Biswas et al. (2015) \\
Chlorella sp. & Naphthalene & Semple et al. (1999) \\
Dunaliella sp. & Mirex & Priyadarshani et al. \\
& & (2011) \\
\hline
\end{tabular}

Table 6 Algae in the bioremediation of Radionuclides

\begin{tabular}{lll}
\hline Microalgae & Radioactive compound & References \\
\hline $\begin{array}{l}\text { Chara, Nitella, Mougeotia, Ulothrix } \\
\text { Stigonema ocellatum, Chloroidium saccharophilum }\end{array}$ & $\mathrm{Cr}$, Sr & Kalin et al. (2004) \\
$\begin{array}{l}\text { Nostoc carneum, Nostoc insulare, Oscillatoria } \\
\text { geminata, and Spirulina laxissima }\end{array}$ & $\mathrm{Cs}$, Sr, Ra, and Am & Fukuda et al. (2013) \\
$\begin{array}{l}\text { Scenedesmus spinosus } \\
\text { Closterium moniliferum }\end{array}$ & $\mathrm{Sr}$ & Pohl and Schimmack (2006) \\
$\begin{array}{l}\text { Dunaliella salina } \\
\text { Anabaena torulosa }\end{array}$ & $\mathrm{Ba}, \mathrm{Sr}$ & Krejci et al. (2014) \\
Cystoseira indica & $\mathrm{Ba}, \mathrm{Sr}$ & Krejci et al. (2011) \\
\hline
\end{tabular}

release, these compounds get suspended in the atmosphere for long time in the form of radioactive dust. This contaminated dust gets settled by the phenomenon of radioactive fallout and causes pollution in soil and surface water bodies which finally gets transmitted to food web (Groudev et al. 2001).

Among all radionuclides, Uranium isotopes (238U, 235U, and 234U) consider as most dangerous element due to its high toxicity and radioactivity (Newsome et al. 2014). Continuous mining and refining of uranium release many tons of radioactive pollutants which increase the risk of air, water, and soil contaminations. Individual can be exposed to uranium by inhalation, ingestion, and dermal contact. Soluble form of concentrated uranium when ingest shows chemotoxic effect to renal tissue which ultimately leads to the failure of kidney (Gavrilescu et al. 2009). In addition, zirconium $(89 \mathrm{Zr}, 95 \mathrm{Zr}, 93 \mathrm{Zr}$, and $88 \mathrm{Zr})$ and thorium $\left({ }^{232} \mathrm{Th}\right.$, $230 \mathrm{Th}$, and ${ }^{229} \mathrm{Th}$ ) are other hazardous radioactive nuclides which show risk of cancer and lungs toxicity in humans. These pollutants also have capability to store in bone tissues and make a significant change in genetic material even after delay exposure (Humsa and Srivastava 2015).

Various studies suggest the potential of algal cells for the removal of radioactive pollutants from waste and its importance for the maintenance of sustainable environment (Table 6). Live or dead cells of Synechocystis sp. can remediate uranyl ion due to the presence of an extracellular hemolysin, such as protein (HLP), which conjugate with polysaccharides and help in the adsorption of radioactive compound (Kalin et al. 2004; Fukuda et al. 2013).

\section{Conclusion}

Nowadays, environmental pollution is a major concern in front of mankind. Due to rapid industrialisation and other anthropogenic activities, the level of various pollutants is increasing in nature which finally enhances the risk of human health. Domestic and industrial effluents, radioactive and pesticide wastes, oil, and their by-products, etc are the main source of pollutants, which contain toxic complex compounds. For safe and sustainable environment, there is an urgent need to enhance awareness about the source of pollutants and to develop an effective methodology for remediation with their real applications. However, the conventional techniques are used often, but they can only transform their form; therefore, the next generation water treatment techniques are in high demand. Algal

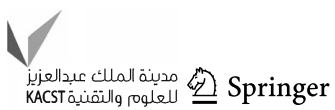


bioremediation is an eco-friendly, cost-effective, precisely sensible technique for resolving the environment problems. However, further research needs to focus on the mechanism behind the remediation on genetic and molecular levels to finally facilitate their exploitation.

Open Access This article is distributed under the terms of the Creative Commons Attribution 4.0 International License (http:// creativecommons.org/licenses/by/4.0/), which permits unrestricted use, distribution, and reproduction in any medium, provided you give appropriate credit to the original author(s) and the source, provide a link to the Creative Commons license, and indicate if changes were made.

\section{References}

Abed RMM, Koster J (2005) The direct role of aerobic heterotrophic bacteria associated with cyanobacteria in the degradation of oil compounds. Int Biodet Biodeg 55:29-30

Acharya C, Chandwadkar P, Apte SK (2012) Interaction of uranium with a filamentous, heterocystous, nitrogen-fixing cyanobacterium, Anabaena torulosa. Bioresour Technol 116:290-294

Akhtar N, Iqbal J, Iqbal M (2004) Removal and recovery of nickel (II) from aqueous solution by loofa sponge-immobilized biomass of Chlorella sorokiniana: characterization studies. J Hazard Mater 108:85-94

Almeda R, Baca S, Hyatt C, Edward JB (2014) Ingestion and sublethal effects of physically and chemically dispersed crude oil on marine planktonic copepods. Ecotoxicology 23:988-1003

Ananya Kamal A, Ahmad IZ (2014) Cyanobacteria "the blue green algae" and its novel applications. Int J Inno Appl Studies 7:251-261

Bashan LB, Bashan Y (2010) Immobilized microalgae for removing pollutants: review of practical aspects. Bio res Technol 101:1611-1627

Bharti PK, Kumar P, Singh V (2013) Impact of industrial effluents on ground water and soil quality in the vicinity of industrial area of Panipat city. J Appl Nat Sci 5:132-136

Biswas K, Paul D, Sinha SN (2015) Biological agents of bioremediation: a concise review. Front Environ Microbiol 1:39-43

Brahmbhatt NH, Patel RV, Jasrai RT (2012) Bioremediation potential of spirogyra sps \& oscillatoria sps for cadmium. Asian J Biochem Pharma Res 2:102-107

Brekke C, Solberg AHS (2005) Oil spill detection by satellite remote sensing. Rem Sens Environ 95:1-13

Brugge D, Buchner V (2011) Health effects of uranium: new research findings. Rev Environ Health 26:231-249

Bulgariu L, Bulgariu D (2014) Enhancing biosorption characteristics of marine green algae (Ulva lactuca) for heavy metals removal by alkaline treatment. J Bioproces Biotechniq 4:146

Castilhos Z, Filho SR, Cesar R, Rodrigues AP, Roberto VB, Jesus ID, Lima M, Faia K, Miranda A, Brabo E, Beinhoff C, Santos E (2015) Human exposure and risk assessment associated with mercury contamination in artisanal gold mining areas in the Brazilian Amazon. Environ Sci Poll Res 22:11255-11264

Chagnon M, Kreutzweiser D, Edward ADM, Morrissey CA, Noome DA, Sluijs JPV (2015) Risks of large-scale use of systemic insecticides to ecosystem functioning and services. Environ Sci Pollut Res 22:119-134

Chekroun KB, Esteban S, Mourad B (2014) The role of algae in bioremediation of organic pollutants. Int Res J Public Environ Health 1:19-32
Cózatl DGM, Gonzále ER, Sánchez RM (2006) Simultaneous $\mathrm{Cd}^{2+}$, $\mathrm{Zn}^{2+}$, and $\mathrm{Pb}^{2+}$ uptake and accumulation by photosynthetic Euglena gracilis. Arch Environ Contam Toxicol 51:521-528

Dabestani R, lvanov IN (1999) A compilation of physical, spectroscopic and photophysical properties of polycyclic aromatic hydrocarbons. Photochem Photobiol 70:1-10

DeLorenzo ME, Geoffrey IS, Philippe ER (2001) Toxicity of pesticides to aquatic microorganisms: a review. J Environ Toxicol Chem 20:84-98

Duruibe JO, Ogwuegbu MOC, Egwurugwu JN (2007) heavy metal pollution and biotoxic effect. Int J Phys Sci 2:112-118

Ebtesam EB, Helmy S, Hussien H, Fahmy M, Ame R (2013) Bioremediation of heavy metal-contaminated effluent using optimized activated sludge bacteria. Appl Water Sci 3:181-192

Fukuda SY, Koji I, Mika Yokoyama A, Takeshi N, Ken I, Isao I, Yoshihiro S (2013) Global searches for microalgae and aquatic plants that can eliminate radioactive cesium, iodine and strontium from the radio-polluted aquatic environment: a bioremediation strategy. J Plant Res 127:79-89

Gavrilescu M, Vasile L, Cretescu I (2009) Characterization and remediation of soils contaminated with uranium. J Hazard Mater 163:475-510

Gibbons D, Morrissey C, Mineau P (2015) A review of the direct and indirect effects of neonicotinoids and fipronil on vertebrate wildlife. Environ Sci Pollut Res 22:103-118

Groudev SN, Georgiev PS, Spasova II, Komnitsas K (2001) Bioremediation of a soil contaminated with radioactive elements. Hydrometallurgy 59:311-318

Gupta VK, Rastogi A (2008) Biosorption of lead(II) from aqueous solutions by non-living algal biomass Oedogonium sp. and Nostoc sp.- a comparative study. Colloids Surf B 64:170-178

Halder S (2014) Bioremediation of heavy metals through fresh water microalgae: a review. Sch. Acad J Biosci 2:825-830

Homaidan AAA, Abdullah AAG, Areej HA (2011) Green algae as bioindicators of heavy metal pollution in Wadi Hanifah Stream, Riyadh, Saudi Arabia. Int J Water Res Arid Environ 1:10-15

Hong Y, Liao D, Chen J, Khan S, Su J, Hu L (2015) A comprehensive study of the impact of polycyclic aromatic hydrocarbons (PAHs) contamination on salt marsh plants Spartina alterniflora: implication for plant-microbe interactions in phytoremediation. Environ Sci Poll Res 22:7071-7081

Houser JB, Venable ME, Sakamachi Y, Hambourger MS, Herrin J, Tuberty SR (2014) Wastewater remediation using algae grown on a substrate for biomass and biofuel production. J Env Prot 5:895-904

Humsa TZ, Srivastava RK (2015) Impact of rare earth mining and processing on soil and water environment at Chavara, Kollam, Kerala: a case study. Proc Earth Planet Sci 11:566-581

Kalin M, Wheeler WN, Meinrath G (2004) The removal of uranium from mining waste water using algal/microbial biomass. J Environ Radioact 78:151-177

Karunya SK, Saranraj P (2014) Toxic effects of pesticide pollution and its biological control by microorganisms: a review. Appl J Hygiene 3:1-10

Khani MH, Keshtkar AR, Meysami B, Zarea MF, Jalali R (2006) Biosorption of uranium from aqueous solutions by nonliving biomass of marinealgae Cystoseira indica. Elec J Biotech 9:1-7

Kim HC, Jang TW, Chae HJ, Choi WJ, Ha MN, Ye BJ, Kim BG, Jeon MJ, Kim SY, HongY S (2015) Evaluation and management of lead exposure. Ann Occup Environ Med 27:30

Kiran B, Thanasekaran K (2011) Metal tolerance of an indigenous cyanobacterial strain Lyngbya putealis. Int Biodeter Biodegrad 65:1128-1132

Kiran B, Kaushik A, Kaushik CP (2007) Response surface methodological approach for optimizing removal of $\mathrm{Cr}(\mathrm{VI})$ from 
aqueous solution using immobilized cyanobacterium, Lyngbya putealis. J Chem Eng 126:147-153

Kponee KZ, Chiger A, Kakulu II, Vorhees D, Wendy HB (2015) Petroleum contaminated water and health symptoms: a crosssectional pilot study in a rural Nigerian community. Environ Health 14:86

Krejci MR, Wasserman B, Finney L, McNulty I, Legnini D, Vogt S, Joester D (2011) Selectivity in biomineralization of barium and strontium. J Struc Bio 176:192-202

Lata S, Singh PK, Samadder SR (2015) Regeneration of adsorbents and recovery of heavy metals: a review. Int $\mathrm{J}$ Environ Sci Technol 12:1461-1478

Liu M, Dong F, Kang W, Sun S, Wei H, Wei Z, Nie X, Guo Y, Huang T, Liu Y (2014) Biosorption of strontium from simulated nuclear wastewater by scenedesmus spinosus under culture conditions: adsorption and bioaccumulation processes and models. Int $\mathrm{J}$ Environ Res Public Health 11:6099-6118

Malik A (2004) Metal bioremediation through growing cells. Environ Int 30:261-278

Matheickal JT, Qiming Y, Woodburn GM (1999) Biosorption of cadmium(II) from aqueous solutions by pre-treated biomass of marine alga Durvillaea potatorum. Water Res 33:335-342

McGenity TJ, Folwell BD, McKew BA, Sanni BA (2012) Marine crude-oil biodegradation: a central role for interspecies interactions. Aqua Biosyst 8:2-19

Mitra N, Rezvan Z, Ahmad MS, Hosein MGM (2012) Studies of water arsenic and boron pollutants and algae phytoremediation in three springs. Iran Int J Eco 2:32-37

Mohany M, Badr G, Refaat I, El-Feki M (2011) Immunological and histological effects of exposure to imidacloprid insecticide in male albino rats. Afr J Pharm Pharmacol 5:2106-2114

Newsome L, Morris K, Lloyd JR (2014) The biogeochemistry and bioremediation of uranium and other priority radionuclides. Chem Geol 363:164-184

Noel SD, Rajan MR (2014) Cyanobacteria as a potential source of phycoremediation from textile industry effluent. J Bioremed Biodeg 5:1-4

Obaidy AHMJA, Lami MHM (2014) The toxic effects of crude oil in some freshwater cyanobacteria. J Env Prot 5:359-367

Olajire AA, Essien JP (2014) Aerobic degradation of petroleum components by microbial consortia. J Pet Environ Biotechno 5:5

Perelo LW (2010) Review: in situ and bioremediation of organic pollutants in aquatic sediments. J Hazard Mater 177:81-89

Persson K, Destouni G (2009) Propagation of water pollution uncertainty and risk from the subsurface to the surface water system of a catchment. J Hydrol 377:434-444

Pohl P, Schimmack W (2006) Adsorption of radionuclides $\left({ }^{134} \mathrm{Cs}\right.$, $\left.{ }^{85} \mathrm{Sr},{ }^{226} \mathrm{Ra},{ }^{241} \mathrm{Am}\right)$ by extracted biomasses of cyanobacteria (Nostoc Carneum, N. Insulare, Oscillatoria Geminata and Spirulina Laxis-Sima) and Phaeophyceae (Laminaria Digitata and $L$. Japonica; waste products from alginate production) at different pH. J Appl Phycol 18:135-143

Prabha S, Kumar M, Kumar A, Das P, Ramanathan AL (2013) Impact assessment of textile effluent on groundwater quality in the vicinity of Tirupur industrial area, southern India. Environ Earth Sci 70:3015-3022

Prakash D, Gabani P, Chandel AK, Ronen Z, Singh OV (2013) Bioremediation: a genuine technology to remediate radionuclides from the environment. Micro Biotech 6:349-360

Priyadarshani I, Sahu D, Rath B (2011) Microalgal bioremediation: current practices and perspectives. J Biochem Tech 3:299-304
Quintana N, Kooy FV, Miranda DVR, Gerben PV, Robert V (2011) Renewable energy from Cyanobacteria: energy production optimization by metabolic pathway engineering. Appl Microbiol Biotechnol 91:471-490

Rani K, Dhania G (2014) Bioremediation and biodegradation of pesticide from contaminated soil and water-a noval approach. Int J Curr Microbiol App Sci 3:23-33

Raouf NA, Al-Homaidan AA, Ibraheem IBM (2012) Microalgae and wastewater treatment. J Biol Sci 19:257-275

Rastogi RP, Sinha RP, Incharoensakdi A (2014) The cyanotoxinmicrocystins: current overview. Rev Environ Sci Biotechno $13: 215-249$

Sahu O (2014) reduction of organic and inorganic pollutant from waste water by algae. Int Lett Nat Sci 8:1-8

Semple KT, Ronald BC, Stefan S (1999) Biodegradation of aromatic compounds by microalgae. Mini review. FEMS Microbiol Lett 170:291-300

Sharma S (2012) Bioremediation: features, strategies and applications. J Pharma Life Sci 2:7-12

Shaikh PR, Bhosle AB (2011) Bioaccumulation of chromium by aquatic macrophytes Hydrilla sp. \& Chara sp. pelagia research library. Adv Appl Sci Res 2:214-220

Shukla D, Vankar PS, Srivastava SK (2012) Bioremediation of hexavalent chromium by a cyanobacterial mat. Appl Water Sci 2:245-251

Sivakumar G, Xu J, Thompson RW, Yang Y, Smith PR, Weathers PJ (2012) Integrated green algal technology for bioremediation and biofuel. Bio Resour Technol 107:1-9

Sun H, Brocato J, Costa M (2015) Oral chromium exposure and toxicity. Curr Envir Health Rpt 2:295-303

Sweetly DZ, Sangeetha Suganthi (2014) Biosorption of heavy metal lead from aqueous solution by non-living biomass of sargassum myriocystum. Int J Appli Inno Eng Manage 3:39-45

Thongpinyochai S, Raymond JR (2014) Using chlorella vulgaris to decrease the environmental effect of garbage dump leachates. J Bioremed Biodeg 5:1-12

Tomer V, Sangha JK, Ramya HG (2015) Pesticide: an appraisal on human health implications. Proc Natl Acad Sci India Sec B Biol Sci 85:451-463

Varsha YM, Naga DCH, Chenna S (2011) An emphasis on xenobiotic degradation in environmental cleanup, review article. J Bioremed Biodegrad 4:1-10

Vijayakumar S (2012) Potential applications of cyanobacteria in industrial effluents-a review. J Bioremed Biodeg 3:1-6

Vilahur N, Vahter M, Broberg K (2015) The epigenetic effects of prenatal cadmium exposure. Curr Environ Health Rpt 2:195-203

Volesky B, Naja G (2007) Biosorption technology: starting up an enterprise. Int J Technol Transf Commer 6:196-211

Wang Y, Tang XW, Wang HY (2015) Characteristics and mechanisms of $\mathrm{Ni}$ (II) removal from aqueous solution by Chinese loess. J Cent South Univ 22:4184-4192

Xenia ME, Refugio RV (2016) Microorganisms Metabolism during Bioremediation of Oil Contaminated Soils. J Bioremed Biodeg 7:1-7. doi:10.4172/2155-6199.1000340

Zaki MS, Mohammad MN, Authman Hossam HHA (2015) Bioremediation of petroleum contaminants in aquatic environments. Life Sci J 12:109-121

Zhang S, Qiu CB, Zhou Y, Jin ZP, Yang H (2011) Bioaccumulation and degradation of pesticide fluroxypyr are associated with toxic tolerance in green alga Chlamydomonas reinhardtii. Ecotoxicology 20:337-347 